\title{
What can IT and Money Laundering Law do to Fight against Cyber Child Sexual Crime?
}

\author{
Go Lisanawati \\ University of Surabaya (UBAYA), East Java, Indonesia \\ lisanawatigo@gmail.com
}

\begin{abstract}
This paper will assess on how technology and anti-money laundering law perspectives can contribute in tackling cyber child sexual crimes. It is normally and classically problem that always emerge in the discussion of law and information technology (IT) is about the increases of crime. But the abnormal and modern problem is about the modernism of crimes with the high-quality level of crime itself. Cyber sexual crime became one of the highest online crimes which conduct through internet. Grooming, voyeurism, cyberstalking, child pornography happens very often in the world. This paper is using normative research methodology of law, by using statute and conceptual approach. The conceptual approach is using to build an ideal concept of prevention and eradication of the crime of online child sexual abuse. This paper is discussed through a qualitative research. The result of this paper is that Information Technology gives contribution in order to present a way out to tackle this problem, for example by giving solution on its surveillance. Other is from the perspectives of law. Money Laundering can assist in tackling online sexual crime toward children, for perpetrator and/or facilitator and/or pther third party who enjoy the illegal gain of this crime.
\end{abstract}

Keywords: IT development, Anti-Money Laundering Crime Law, Prevention of Crime, Eradication of Crime, and Cyber Child Sexual Offense

\section{Introduction}

Cyber crime is a result of a modern society. It can not denied that modern society has created a modern and sophisticated crime. Kirwan \& Power (2013) explains: "When considering the social construction of crime, cybercrime is a very interesting case. Some cybercrimes were already defined as criminal events due to their similarity to offline counterparts. These type of offences are often considered in the literature to be 'old wine in the new bottles', as it is thought the nature of the crime has not changed, but merely the mechanism by which the crime has been carried out. Offences such as the distribution of child pornography online can be included in this categorisation". More sophisticated technology, means more sophisticated crimes. The 6th UN Congress on the Prevention of Crime and the Treatment of Offender mentioned:"... the farther the law was removed from the feeling and the values shared by the community, the greater was the lack of confidence and trust in the efficacy of the legal system". The law and its legal system will face a great challenges and shortfall in term of following cyber crime. It deals with so many forms. From old wine in the new bottle to a new wine in the new bottle, until new wine without bottle. From crimes against person, property, technology security, etc. Therefore Cyber crime itself needs multidisciplinary approach to handle. Sometimes it is called as online crime, virtual crime, cyber criminals, digital crimes, cyber offense, telematics crime, electronic crime, etc (this article choose the word cyber crime). To explain about the forms of cyber crime, Smith et al. (2004) mentions: Arguably a distinction could be made between cybercrime (a singular concept of crime that could encompass new criminal offences perpetrated in new ways) and cyber crime (a descriptive term for a type of crime involving conventional crimes perpetrated using new technologies). Criminal offences that fall into the former category might include cyberstalking and cyberterrorism.

Some have argued that virtual crime should be categorized as separate from and less serious than terrestial crime, altough Williams (2001, pp. 152 - 3) believes that "the "real" and the "virtual" are not separate experiences and as such the nature of online communication enables a perpetrator to inflict recognisable levels of harm upon a victim via textual slurs and abuse'. We prefer to through the use of, or against, digital technologies. The form of cyber crime is actually developed and manisfested in many ways and forms. For some time, cyber crime appear in the new form even when it is essentially an old crime; or it appear in the new form and the essential is new crime (such as cracking, phising, voyetourism). Further, cyber crime arise 
as a new crime without bottle, in its derivatives is occuring such difficult and complicated crime to handle. Online child sexual offenses, such as tourism, pornography, voyetourism, trafficking, prostitution, etc are the possible crime that may appear in the variant forms. Shinder (2002), as quoted by P. Golose, mention that there is two categorize of cyber crime: 1 . Cybercrime with violence, which is including cyberterrorism; assault by threat; cyberstalking; and child pornography. 2. Cybercrime without violence, which is including cybertrespass; cybertheft; cyberfraud; destructive cybercrime; and other nonviolent cybercrimes (including cyber prostitue ads). The categorize from Shinder has remind that cybercrime against children can appear as violence and also non violence.

The nature of cyber crime itself is dangerous, and it puts children in threatening positions. Even though people may said that it is old crime, but people may think that its form gives complex effects to children. Russel Smith et al. (2004) then mention:

The concept of cyber crime we have chosen to adopt derives from the now widely accepted conception of cyber crime as entailing conduct prescribed by legislation and/or common law as developed in the courts, that:

- Involves the use of digital technologies in the commission of the offence, or

- Is derived at computing and communication technologies themselves; or

- Is incidental to the commission of other crimes.

Moreover, cyber crime can be the predicate crime which result other crime. It might derived money laundering crime. Therefore money laundering approach shall be applied to tackle cyber crime. Some cases related with sexual crime towards children in Indonesia has been detected through money laundering approach. In so many ways, the perpetrator of child sexual crime can commit their crime by going online. Internet has attaracted paedophilia, predators, and/or other perpetrator in exploring more children. Malesky (2007), as quoted by Kirwan \& Power (2013), then mentions: "that three-quarters of men who perpetrated or attempted to perpetrated contact sexual offences against minors using the internet monitored chatroom dialogue". Internet is easily to facilitating perpetrator to commit sexual crime against children. Police Officer Bonaparte (2012) through his presentation mention a fact that cyber child sexual crime in Indonesia occurs such as a list of fact below:

Indonesian children were recruited into sex trafficking through Internet, "social networking media"; Photo sharing technologies are used for the instantaneous and mass dissemination of sexually abusive images of children for personal and commercial reasons; E-commerce tools are used to conduct the financial transactions associated with the sale of images and videos of child exploitation, and the outright sale or rent of victims of human trafficking; Certain websites pretend to offer "escorts services" (while actually they are online solicitation for sexual activity involving minors); In some case, children lured by offenders into sexual exploitation by enticing them with mobile phones, a nice house and other facilities; Pedophiles bribed parents with money, food, other basic needs and household goods. They were regarded as 'Santa Clauses' in those poor families. They won the hearts of locals by claiming to be "foster fathers" and promised parents to provide a better education and future for their children; Majority of the parents (of exploited children) work as cheap unskilled laborers or farmers, who have to spend most of their time in the field, and gave wide space for offenders to do their sexual misconduct toward children; Customers negotiate directly with the child prostitute in order to receive sexual gratification, or through an intermediary (pimp) who controls or oversees the prostitute's activities for profit and deliver those minors to hotels, brothels, villas in some areas; Many hotels will shamelessly arrange for a young school girl or boy to come to guest room for sex; Some minors found been sent to prostitution areas and brothels abroad.

Unfortunately the law enforcement in Indonesia remain shows that the enforcement is not yet reach effective levels since the major causes of child sexual abuse is not yet solved.

A. Santoso, vice of head of Indonesian Financial Transaction Reports \& Analysis Centre (INTRAC), as quoted from VIVANEWS (2014) explains some facts that:

Saya dapat laporan bahwa ada 200 paedofil masuk Indonesia. Kami sudah telusuri ada di mana. Ini semacam wisata bagi mereka (paedofil)..

Para EO (= Event Organizer) itu yang kemudian mengarahkan para turis paedofil untuk masuk ke daerahdaerah tertentu, tujuannya mencari target anak-anak di perkampungan. Daerah-daerah yang disasar antara 
lain beberapa daerah di Sumatera, Cianjur, Semarang, Solo, Palu, dan Bali... Anak-anak yang mereka sasar pun beragam. Kaum paedofil membaginya ke dalam kategori, yakni anak remaja muda dari usia 9 hingga 11 tahun, dan anak remaja berusia 12 - 15 tahun. Kalau sudah 15 tahun ke atas biasanya sudah pelacuran anakanak... Modus yang mereka gunakan juga bermacam-macam. Para paedofil itu sudah mendapat informasi sebelum masuk ke daerah-daerah di Indonesia melalui internet... Bekal informasi yang diterima kaum paedofil itu antara lain, dengan menyiapkan dana bagi warga kampung...

(Free Translation:I got report that there are 200 paedophiles enter Indonesia. We have traced them everywhere. It is like a tourism activity for them (paedophiles)... The EO (Event Organizer) then direct the paedophiles tourist to certain areas, with destination to look for the children in remote area as target. The destination areas are some areas in Sumatera, Cianjur, Semarang, Solo, Palu, and Bali... The targeted children are various. Paedophiles devided them into categories, they are young teenager kids from age of $9-11$ years, and teenager from age 12 - 15 years. If above age of 15, usually categorized as child prostitution... They use various modus. Paedophiles has information before entering the certain areas in Indonesia through internet... The informafion that has been received by paedophiles told them to prepare funds for the villagers...)

A. Santoso, as quoted in jakarta.sorotnews.com (2014) then add an information:

Apalagi Indonesia sudah menjadi negara tujuan. Salah satu buktinya, adanya aliran transaksi keuangan terkait child sex tourism. Hal itu yang akan ditelusuri oleh Pusat Pelaporan dan Analisis Transaksi Keuangan. PPATK dan Polri sudah membentuk gugus tugas untuk membongkar jaringan yang menawarkan child sex tourism... PPATK bekerjasama dengan Polri akan berusaha mengungkap jaringan-jaringan melalui penelusuran aliran uang, intelejen lapangan, maupun dari patroli Polri di dunia maya

(Free Translation: Furthermore, Indonesia has become destination country. Shown by the fact where there is financial transaction flows relating child sex tourism. There will be tracing by INTRAC. INTRAC and Indonesian National Police has set up a task force to tackle the networks who offer child sex tourism... INTRAC in the coordination with Indonesian National Police will discover the networking through money flows tracing, field intelligence, and Indonesian Police watchs through virtual world...)

Through the data from A. Santoso above it can be said that money laundering plays a great part in preventing and eradicating child sexual crime both in physical and virtual worlds.

\section{Methodology}

Qualitative research methodology and juridical normative metholodology, through statute and conceptual approach, will be operated to do this article writing. Moleong (2009) explains: "penelitian yang menghasilkan prosedur analisis yang tidak menggunakan analisis statistik atau cara kuantifikasi lainnya" (Free Translation: the research will result ain analysis which is not using statistical analysis or other quantitative procedure). The conceptual approach will operate to get a conceptual result to give solution for this problem of study in this article.

The Costs of Cyber Child Sexual Crime From Offender To Victims Perspectives: As a crime, cyber crime has been existing in so many forms and brought negative impacts to the victims. As mentioned by Shinder above, cyber crime can happen with violence and without violence. Even though cyber crime is abstract but the effect is real. In this article will discuss about online child sexual crime and other variant of crime that may appear. Child sexual abuse as arranged in the Optional Protocol on the sale of children, child prostitution, and child pornography has been a major and serious problem for children. In fact, this crime is also occuring in other form called sexual tourism. UNICEF (2009) describes:

Modern technologies have also led to new challenges and concerns, with disconcerting worldwide dimension. The explosion of these technologies, particularly the internet, has brought many benefits to humanity, but the consequences of their misuse are now evident... As widespread and uncontrolled online access became commonplace, countless paedophile websites appeared, and child pornography made its way into the global and connected world on the screens of personal computers.

As a result of the growing globalization of child exploitation, the international community took immediate action. Using the same information technologies that facilitate the exploitation of children, people dedicated 
to child protecion have attempted to increase global awareness. The explosive growth in circulation of information about old and new forms of child exploitation led to an innovative global movement to fight the practice. The explanation above shows how vulnerable children are and their protection when dealing with information technology (IT). IT can brings an old or a new crimes and even its derivative. Thus the issues of child protection is important to be discussed and will find solution. Vulnerability of children in the IT development shall be put as main concern for everyone, including the IT expert. Child sexual exploitation can be understood from the definition given by UNICEF (2001) that is "Commercial sexual exploitation of children as 'a sexual abuse by an adult accompanied by remuneration in cash or in kind to the child or third person(s)". The definition of commercial sexual exploitation has given a very specific term of who is the offender, what the offender do to children, and what are the things that followd the action. Adult can do sexual abuse to children though abusing sexually accompanied by remuneration, both in cash and in kind to the child itself of third person(s). This kind of third person(s) is a middle man who facilitate the crime of sexual abuse to children. Thus both of offender and the third person(s) shall be punished. The common problem identified through the problem of sexual exploitation is that victim usually came from poor family. The third person(s) can be their parent. What can law do for that?

Article 2 of the Optional Protocol defines Sale of Children as:"any act or transaction whereby a child is transferred by any person or group of persons to another for remuneration or any other consideration". Children are in the sale or traffic constallation to get remuneration. Indonesia as a country who really concern with the problem of trafficking, has mentioned in its Law Number 21 of 2007 concerning Eradication of human trafficking, with more specific in Article 17, the gravity of punishment for person who traffic children will be added for $1 / 3$. While the Law Number 23 of 2002 concerning Children's protection has prohibited the criminal act of child trafficking. Child prostitution regarding Article 2 of the Optional Protocol of CRC is "the use of a child in secual activities for remuneration or any other form of consideration". In a simple way, child prostitution can be understood from the construction that adults using children to be involved in any sexual activity to get payment or other kinds of remuneration, through any action of offering, acquiring, procuring, or providing a child to do child prostitution activity.

The big problem appearing in online context nowadays is about child pornography. Article $2 \mathrm{c}$ of the Optional Protocol of CRC defines Child pornography as "any representation, by whatever means, of a child engaged in real or simulated explicit sexual activities or any representation of the sexual parts of a child for primarily sexual purposes". Sjahdeini (2009) notes:

Para pelaku kejahatan pornografi anak (molester) pada saat ini menggunakan teknologi komputer untuk mengorganisasi dan melakukan pengumpulan gambar-gambar ilegal ini. Di samping mereka juga menggunakan Internet untuk menambah jumlah kumpulan gambar-gambar ini. Pembuatan gambar-gambar ilegal tentang anak-anak ini sangat mahal di Internet, karena para pelakunya memiliki status yang lebih tinggi dibandingan dengan para pelaku di bidang ini yang masih melakukan pendistribusian dan perdagangan gambar-gambar tersebut secara tradisional (Free Translation: The offender of child pornography (molester) nowadays using computer technology for organizing and collecting illegal pictures. They use Internet also to add the number of pictures. Producing of illegal child pictures are very expensive in the Internet, because this type of offender has higher status than offender who distribute and sale the pictures traditionally)

The opinion of S.R. Sjahdeini above could give description that the more sophisticated the distribution of child pornographic pictures, the more expensive its value. Clough (2010) gives other opinion on Child pornography through Court, as below:

The court accepted the prosecution's submission that prohibiting the possession of child pornography is linked to reducing secual abuse of children in five ways:

- Child pornography promotes cognitive distortions such that is may normalise sexual activity with children in the mind of the possessor, weakening inhibitions and potentially leading to actual abuse. While acknowledging that the evidence is 'not strong', the court held that evidence does support a link between child pornography reducing peadophile's defences and inhibitions against secual abuse of children.

- Child pornography fuels fantasies that incite offenders. While not all offenders involved with child pornography are necessarily involved in direct sexual assault in children, the court accepted that there are some studies which suggest that child pornography may fuel fantasies and incite certain 
people to offend, and that this is a sufficient rational connection to justify criminalisation as there is no need for unanimity of specific opinion.

- Prohibiting the possession of child pornography assists law enforcement efforts to reduce the productions, distribution and use of child pornography that result in direct harm to children. Although this rationale could not be the sole justification for abridging a Charter right, the court held that it was nonetheless a positive side-effect of the law.

- The court regarded the evidence as 'clear and uncontradicted' that child pornography is used for grooming and seducing victims...

- Some child pornography is produced using real children. The viewer is therefore in a sense an accessory after the fact to an act of child abuse by providing a market for it.

Child pornography is harmful and should be stopped. Offender should not do more longer action to abuse children. It will be harmful for children if they are engaged in child pornography through taking real children to produce any kind of child pornography. Thus law enforcement agents shall work very hard to prevent and eradicate this kind of action. Once again Clough (2010) reminds: "the harms of child pornography extend far beyond direct, physical exploitation. It is harmful whether it involves real children in its production or whether it is a product of the imagination. In either case, child pornography fosters and communicates the same harmfulm dehumanizing and degrading message". Both virtual and real, children are potential victim. Other dangerous activity relate with child sexual abuse is as described in the explanation before, that is called as child sexual tourism. Childsafe International (2012) defines child sexual tourism as "the commercial sexual exploitation of children by foreigners. It usually refers to: 1 . Persons who travel from their own country to another to engage in sexual acts with children, or 2. Foreigner who engage in sexual activity with a child while overseas; 3 . It often involves a third party who procures a child from local communities". The definition above mentioned 3 kinds of offender of child sexual tourism, that is domestic offender; foreigner offender; and third party as middle man. The construction of crime of child sexual tourism is very difficult to define. State country should regulate more strict on the tourism regulation. The offender can easily use tourism and social visit reason to conceal their intent to abuse children sexually. Even though Shinder categorize advertisement of sexual activity in cyber crime non violence, but it shall be reconsidered that advertisement related to crime of sexual abuse activity has the same dangerous effect as sexual abuse itself. Offering all material related with the child sexual abuse through any means shall be punished since it has the same impact to children.

Other form of crime which have been affected by abuse of Internet is grooming. A.A. Gillespie, as quote by Clough (2010) defines Grooming as "the process by which a child is befriended by a would-be abuser in an attempt to gain the child's confidence and trust, enabling them to get the child to acquise to abusive activity". Other is voyeurism, which was defined by Clough (2010), that "goes beyond being watched without one's knowledge. It is concerned with the convert observing and recording of other, for a special purpose, in situations which may broadly be described as 'private'. Although successful in some cases, existing offences are generally ill-suited to the task. Offences such as stalking or trespass may require the offender to be physically proximate to the victim". The Law Number 11 of 2008 concerning Electronic Information and Transaction of the Republic of Indonesia actually prohibited any form of distribution, transmission, and availability of something with obscene material content, which was conduct ed intentionally and against the law. (vide Article 27 (1)). The regulation mentioned by Article 27 (1) above is actually in wide scope, since it is relating with obscene material. And regarding with child protection, Article 52 (1) of the Law Number 11 of 2008 is giving additional $1 / 3$ gravity of punishment to any kind of violation containing obscinity or sexual exploitation to child. Concerning the appearing of many forms of cyber crime which may against children and abusing them sexually, it is making important to reconsider about what IT should contribute to give protection to children. Campaign about Internet safe is a way to raise awareness to children. The other idea which may developed by all IT Expert to protect chidren from any forms of child sexual abuse is by using photo DNA. The technology of Photo DNA can be used to detect the footprint of offender. As Kirwan and Power (2013) try to campaign, that is developing a contract of internet use which is suitable for a young adolesce and older teenager or a younger child by considering what elements of online behaviour should be covered, what they feel an acceptable amount of time to spend online daily. More importantly, IT Expert should create a tool to identify everyone who using online application. For example developing the principle of non repudiation in collaborating with camera using. 


\section{Money Laundering Approach Assistance in Tackling Online Child Sexual Crime}

As understood from literature, money laundering is actually developed to stop the predicate crime, proceeds of crime and/or any kinds of expansion of the application field to other offences. Stessen (2000) mention: Criminals who, through their criminal activities, dispose of huge amounts of money, need to give this money a legitimate appearance: they need to 'launder' it. The phenomenon of money laundering is essentially aimed to two goals: preventing 'dirty money' from serving the crimes that generated it, and ensuring that the money can be used without any danger of confiscation.

Money laundering shall has predicate crime which is resulting proceeds of crime. To disguise that the property or money is derived from illegal activity, the perpetrator should to do laundering on that property. The United Nation Convention Against Illicit Traffic in Narcotics, Drugs and Psychotropic of 1988 defines Money Laundering as:

The conversion or transfer of property, knowing that such property is derived from any serious (indictable) offence or offences, or from act of participation in such offence or offences, for the purpose of concealing or disguising the illicit of the property or of assisting any person who is involved in the commission of such an offence or offences to evade the legal consequences of his action; or the concealment or disguise of the true nature, source, location, disposition, movement, rights with respect to, or ownership of property, knowing that such property is derived from a serious (indictable) offence or offences or from an act of participation in such an offence or offences.

Money laundering approach is a very specific and characteriscal apporach that is often difficult to understood. It is not easy to implement money laundering in court. But anyhow money laundering is quite danger since money laundering does not only threaten the stability of economy and the integrity of financial system, but it also can endanger the essential values of the social life and nationhood. The offender of the money laundering crime will hide or evade the sources and origin of Assets which derived from the criminal act. The process will be difficult to be traced by the law enforcement officer. The concept of money laundering put offender of predicate crime and its proceeds of crime will be traced, and shall be forfeited that assets, not only to stop the perpetrator to enjoy the illegal gain, but also to prevent other crimes which may financed by the illegal gain. Henceforth such result of criminal action shall be confiscated of forfeited. Money laundering however is getting more complex, transboundaries, and having various modus in its development. Money laundering can be done through 3 (three) stages, called Placement, Layering, and Integration. The stages are not accumulated. It can be happen through one stage and/or two and/or all stages. In short, it can be easily understood that money laundering did not need complete stage, but it must be done with intention.

Through the Law Number 8 of 2010 concerning prevention and eradication of money laundering crime, Indonesia has criminalised money laundering. The perspective that is developing through benefit cut-off approach. Illegal gain money that become the blood of the predicate crime should be cut off. The Law Number 8 of 2010 prohibited 3 (three) kinds of money laundering which is derived from any Predicate Crime as mentioned in Article 2, as below:

- Result of the criminal act shall be the Assets acquired from the criminal action as follow: a. Corruption; b. Bribery; c. Narcotics; d. Psychotropic; e. Labor smuggling; f. Immigrant smuggling; g. Criminal act in banking; h. Criminal act in capital market; i. Criminal act in insurance; j. Customs; k. Excise; l. Human trafficking; $m$. Trade of illegal fire arm; $n$. Terrorism; o. Kidnapping; p. Burglary; q. Embezzlement; r. Fraud; s. Money counterfeiting; t. Gambling; u. Prostituting; v. Criminal act in taxation; w. Criminal act in forestry; $x$. Criminal act in environment; $y$. Criminal action in marine and fishery; z. Other criminal actions of which is treated with the imprisonment for 4 (four) years or more.

Of which is committed in the territory of the Republic of Indonesia and in the outside of the Territory of the Republic of Indonesia and such criminal act is called as criminal act according to the Indonesian law.

- Assets of which are recognized or of which are reasonably alleged to be used and/or directly or indirectly used for the terrorism activity, terrorism organization, or individual terrorism shall be equalized as the result of criminal act as set forth in section (1) point $\mathrm{n}$ above. 
To find the predicate crime of cyber child sexual abuse, it can be constructed from the criminal act which have been bold above. However, cyber child sexual abuse will criminalize the act regarding with child (=human) trafficking, and also prostitution. Other predicate crime which can be cosntructed for cyber child sexual crime is using the Law Number 11 of 2008 of the Republic of Indonesia, Article 27 (1) as explained in previous page. The violation of Article 27 (1) as mention in Article 45 (1) will impacting person(s) who violate will be punished with imprisonment for maximum 6 (six) years and/or fine of Rp. 1.000.000.000, 00 (One billion rupiahs). About the criminalisation of money laundering, Article 3, 4, and 5 of the Law Number 8 of 2010 has been regulated. Article 3 was regulated in purpose to tackle the money laundering process of a predicate crime's offender and also money laundering's offender. Article 3 regulate:

Anyone, who places, transfers, forwards, spends, pays, grants, deposits, takes to the abroad, changes the form, changes to the currency or securities or other deeds towards the Assets of which are recognized or of which are reasonably alleged as the result of criminal action, as set forth in Article 2 (1) with the purpose to hide or to disguise the origin of Assets..

Article 3 above can be implemented to the offender of cyber child sexual crime. It means Article 3 will actively punish the offender of predicate crime and also money laundering crime.

Article 4 regulate:

Anyone, who hides, or disguise the origin, source, location, purpose, transfer of right, grant, deposit, exchange, or utilizes the Assets of which are known by him or of which are reasonably alleged as the result if the criminal act, as set forth in Article 2 (1)...

Article 4 will be subject to the intermediate person. In the case of cyber child sexual abuse it may third person(s) or the organizer. The organizer or third person(s) may facilitate the hide or disguise process of illegal money from the offender.

Article 5 (1) regulate:

Anyone, who accepts or who takes control on placement, transfer, payment, grant, deposit, exchange, or utilizes the Assets of which are known by him or of which are reasonably alleged as the result of the criminal act, as set forth in Article 2 (1)...

Article 5 (1) above can be elaborated by implementing to the receiver of the illegal gain from offender. It might the third person who receive money from the offender of cyber child sexual abuse. Related with the regime of money laundering, which will stop the crime and the other proceeds of crime, then confiscation or forfeiture will play important role here. Forfeiture shall operate in conducting benefit cut-off perspectives. F. Frattini (2007) mentions: "No matter how effective preventive measures may be, crucial to the success and credibility of the anti-money laundering scheme is that further action is taken 'down the pipeline'..." While the European Council affirmed that: "Money laundering is at the very heart of organized crime. It should be rooted out wherever it occurs". Thus, the confiscation or forfeiture will play important role in stopping the pipeline which derived from assets or money which becomes the heart of crime itself. The Law Number 8 of 2010 has regulated about the mechanism of forfeiture, which is known as Postponement of Transaction (Article 26); Temporary discontinuity of transaction (Article 66), and Blocking mechanism (Article 71). It shall be applied without delay once the reporting parties find a proper evidence that the there is a money laundering process happen. Therefore, the scheme below will assist in understanding how money laundering can play a role in tackling cyber child sexual crime. 
Figure 1: AML model

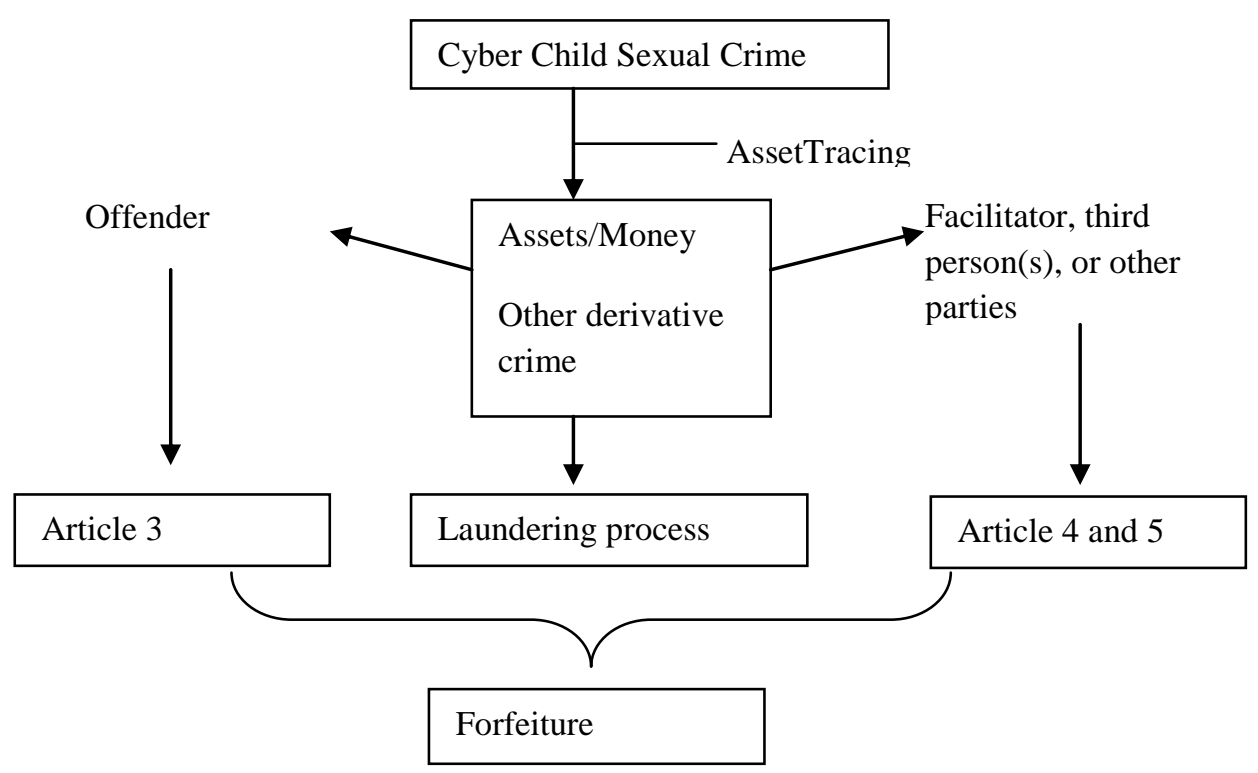

Yusuf (2014) in conclusion explained: "Perang melawan para pelaku pencucian uang tidak hanya mengurangi kejahatan di bidang keuangan, tetapi juga menghalangi mereka untuk melakukan kejahatan serius (serious crime) lainnya" (Free translation: the war against offender of money laundering won't reduce the financial crime itself, but barred them to commit other serious crime). Child sexual abuse is a serious and dangerous crime, both through physical and through cyber medium. Therefore it needed extraordinary effort to tackle it. From the explanation above, it can be understood from the diagram mention below:

\section{Figure 2: Result}

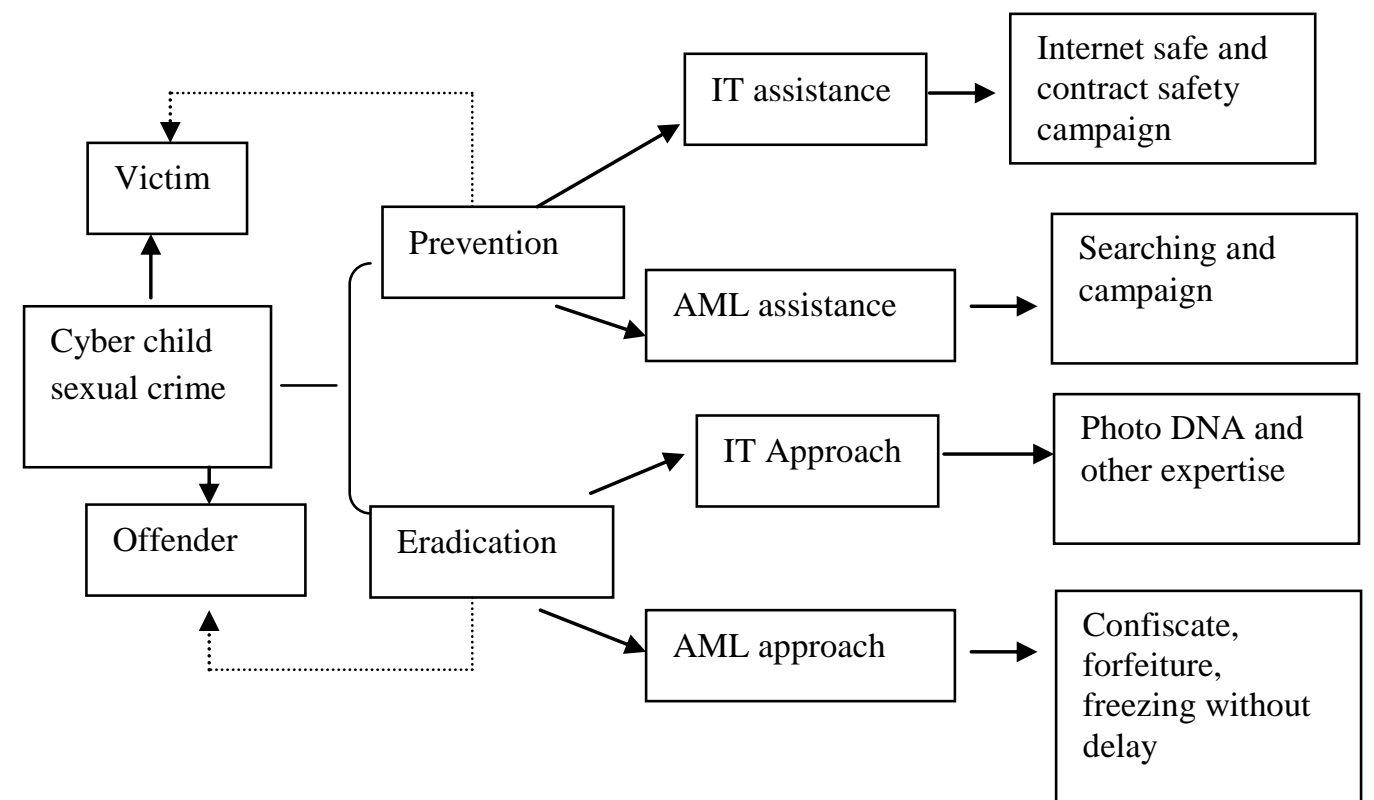

Solution: In understanding the dangerousity of cyber child sexual crime, it needs extraordinary effort from the law and the law of enforcement itself. Children are potential victims of the development of Information Technology (IT). Online crime has put children as a victim which can be exploitated sexually by the offender and/or the facilitator (third person(s) to get benefit. The complex modus of the cyber crime, shall be tackled down seriously. Both of IT and Money laundering should be collaborated and operated well since they have very significant role in reducing and combating the crime of child sexual abuse through online. 


\section{Recommendation}

The law enforcement agents should considering to start in using money laundering law in order to tackle the crime of cyber child sexual abuse, and reintegrated it everytime there is offender is charge with child sexual abuse. It will give effective impact to cut the proceeds and further action of child sexual abuse, and forfeit any kinds of benefit which may derived from the crime.

\section{References}

Arpas, M. (2014). PPATK akan usut Aliran Dana Untuk Kejahatan Seks Anak. Jakarta.sorotnews.com. p.1 Bonaparte, N. (2012). The Effectiveness of Indonesian Nation Legislation in Addressing Sexual Crimes Against Children Online.[PowerPoint slides]. Conference on Sexual Crimes Against Children Online: Law Enforcement and Regional Cooperation, Jakarta, October 29-30, 2012.

International, C. (2012). Sexual Abuse and expolitation of Children. Retrieved from http://www.childsafeinternational.org

Clough, J. (2010). Principles of Cybercrime. United Kingdom: Cambridge University Press, 252-253, 272, 291, 332,389

Frattini, F. (2007). Initiatives of the European Commission. In Muller, W.H, Kalin, C.H \& Goldsworth, J.G. (eds), Anti Money Laundering: International Law and Practice (63), United Kingdom: Henley\& Partners

Golose, P. R. (2008). Seputar Kejahatan Hacking: Teori dan Studi Kasus. Jakarta: YPKIK, 29

Kirwan, G. \& Power, A. (2013). Cybercrime: The Psychology of Online Offenders. United Kingdom: Cambridge University Press, 3(18), 132, 138

Malau, I. L. F. (2014). Astaga! Indonesia Jadi Tujuan Wisata Ratusan Paedofil. VIVANEWS (viva. co.id), pp. 1-2

Moleong, L. J. (2009). Metodologi Penelitian Kualitatif. Bandung: Remaja Rosdakarya, 6 www.nsopw.gov

Shinder, D. L. (2002). Scene of the Cyber crime: Computer Forensics Handbook. Syngress Publishing Inc. 88 Hingham Street, USA.

Sjahdeini, S. R.( 2009). Kejahatan \& Tindak Pidana Komputer. Jakarta: Sinar Grafiti, 178

Smith, R. G., Grabosky, P. \& Urbas, G. (2004). Cyber Criminals on Trial. United Kingdom: Cambridge University Press, 6, 7

Stessens, G. (2000). Money Laundering: A New International Law Enforcement Model. United Kingdom: Cambridge University Press, 5

UNICEF. (2009). Handbook on the Optional Protocol on the Sale of Children, Child Prostitution and Child Pornography. Italy: UNICEF Innocenti Research Centre, p. viii

Williams, M. (2001). The Language of Cybercrime', in Wall, D. S. (ed.), Crime and the Internet, Routledge, London, 152-166.

Yusuf, M. (2014). Mengenal, Mencegah, Memberantas Tindak Pidana Pencucian Uang. Jakarta: PPATK, 131 